\title{
Selection in segregating populations of ornamental pepper plants (Capsicum annuum L.) using multidimensional scaling ${ }^{1}$
}

\author{
Maria do Perpetuo Socorro Damasceno Costa ${ }^{2}$,Elizanilda Ramalho do Rêgo ${ }^{3 *} \mathbb{D}$, Priscila Alves Barroso \\ Anderson Rodrigo da Silva ${ }^{5}$ Mailson Monteiro do Rêgo ${ }^{6}$
}

$10.1590 / 0034-737 X 202067060007$

\begin{abstract}
Multidimensional scaling is a multivariate analysis technique that can be used to exploit genetic diversity, aiming at the selection of Capsicum genotypes with desirable characteristics for in-pot ornamental purposes. This work aimed to select genotypes with ornamental potential within $\mathrm{F}_{4}$ populations of ornamental pepper plants. Three $\mathrm{F}_{4}$ families were used $(17.18,30.16$, and 56.8). The genotype distance matrixes between genotypes were estimated based on qualitative and quantitative descriptors, both separately, combining the standardized distances of Gower and Mahalanobis, respectively. The relation of the distance between genotypes was graphically studied through non-metric multidimensional scaling. Kruskal' Stress was used as the measured misadjustment of the $n M D S$ solution. There is genetic diversity within the analyzed families, allowing to practice selection. The selection in family 17.18 of genotypes 6 and 32 is recommended, as well as in family 30.16 of genotypes 22 and 4, and family 56.8 of genotypes 15 and 36, since they present important characteristics for ornamental purposes. The selection of genotypes is more efficient when using mixed data since it provides a more complete genetic diversity in an improvement program.
\end{abstract}

Keywords: Multivariate analysis; genetic diversity; Gower; Mahalanobis.

\section{INTRODUCTION}

Pepper (Capsicum spp.) is one of the most important and most cultivated horticultural plants in the world (Bosland \& Votava, 2012; Silvar \& García-González, 2017). They can be used in culinary, pharmaceutical and cosmetical industries, as well as ornamental plants (Rêgo et al., 2015a; Cardoso et al., 2018).

In ornamentation, pepper plants have been highlighted for their growing and continuous receptivity by the consuming market (Finger et al., 2015; Rêgo \& Rêgo, 2018). This growing interest for ornamental peppers occurs due to the great diversity observed in several features, such as size, leaves, fruit color, and adequate architecture (Stommel \& Bosland, 2006; Padilha et al., 2016).

In spite of the diversity found in this genus, only some ornamental varieties are available in the Brazilian market
(Rêgo et al., 2015a; Neitzke et al., 2016). It is, therefore, important to insert pepper plants in improvement programs aiming at the development of new varieties for ornamental purposes (Rêgo et al., 2015b; Vasconcelos et al., 2012; Silva et al., 2017).

The Federal University of Paraíba (UFPB) has developed in the last few years an improvement program for ornamental pepper plants whose purpose is the development of new varieties, based mostly on hybridization, generating segregating populations and allowing for the improvers to select superior genotypes, with desirable characteristics for in-pot cultivation (Silva Neto et al., 2014; Rêgo et al., 2015a; Mesquita et al., 2016; Lima et al., 2019; Fortunato et al., 2019; Nascimento et al., 2019; Pessoa et al., 2019). In this perspective, the study of the genetic diversity among genotypes in segregating

\footnotetext{
Submitted on February 14th, 2020 and accepted on August 17th, 2020.

${ }^{1}$ This work is part of the Doctoral Thesis of the first author.

${ }^{2}$ Universidade Federal da Paraíba, Centro de Ciências Agrárias, Programa de Pós-Graduação em Agronomia, Areia, Paraíba, Brazil. agro30costa@gmail.com

${ }^{3}$ Universidade Federal da Paraíba, Centro de Ciências Agrárias, Departamento de Ciências Fundamentais e Sociais, Areia, Paraíba, Brazil. elizanilda@cca.ufpb.br

${ }^{4}$ Universidade Federal do Piauí, Laboratório de Melhoramento e Análise de Dados, Bom Jesus, Piauí, Brazil. pa.barroso@ufpi.edu.br

${ }^{5}$ Instituto Federal Goiano, Urutaí, Goiás, Brazil. anderson.silva@ifgoiano.edu.br

${ }^{6}$ Universidade Federal da Paraíba, Centro de Ciências Agrárias, Departamento de Ciências Biológicas, Areia, Paraíba, Brazil. mailson@cca.ufpb.b

*Corresponding author: elizanilda@cca.ufpb.br
} 
Capsicum populations can be explored through the use of multivariate analysis.

Multidimensional scaling is a multivariate analysis technique that can be used in the study of the genetic diversity in Capsicum since it allows to graphically represent the distances of the genotypes through dimensional reduction. The individuals are, therefore, arranged as points in space, generally bidimensional or tridimensional, in which it is possible to observe the similarity and the dissimilarity between individuals (Borg $\&$ Groenen, 2005; Manly, 2008). The use of this analysis in the study of genetic diversity in improvement programs was performed in studies with cocoa (Leal et al., 2008), garlic (Silva et al., 2014), broad bean (Barroso et al., 2019), and a segregating population of Capsicum (Pessoa et al., 2019). Then, this analysis may be appropriate for studies on genotypic dispersion, since the conventional improvement program is based mainly on phenotypic data, which are based on qualitative and quantitative characters (Barroso et al., 2019). Furthermore, it may also be important in the selection of more divergent individuals with desirable features for the improvement program.

This work aimed to select genotypes with ornamental potential within populations of the fourth filial generation $\left(\mathrm{F}_{4}\right)$ of ornamental peppers through multidimensional scaling.

\section{MATERIAL AND METHODS}

The experiment was performed in a plant nursery, at the Laboratory of Plant Biotechnology of the Center of Agrarian Sciences of the Federal University of Paraíba (CCA/UFPB), in the municipality of Areia-PB, at an elevation of $618 \mathrm{~m}, 06^{\circ} 57^{\prime} 48^{\prime \prime} \mathrm{S}$ latitude and $35^{\circ} 41^{\prime} 30^{\prime \prime} \mathrm{W}$ longitude.

Three $\mathrm{F}_{4}$ families were used $(17.18,30.16$, and 56.8) each one constituted by 45 individuals originated from the UFPB 77.2 x UFPB 134 crossing, conducted by the genealogical method.

The sowing was performed in expanded polystyrene trays, with 200 cells filled with the Plantmax $\mathrm{HT}^{\circledR}$ commercial substrate. Thirty-five days after sowing, when the plantlets presented three pairs of definitive leaves, they were transplanted to plastic pots with volumetric capacity for $900 \mathrm{ml}$, containing the Plantmax $\mathrm{HT}^{\circledR}$ commercial substrate. Whenever necessary, the cultural practices recommended for the crop were performed (Filgueira, 2000).

Twelve quantitative descriptors were used, namely: plant height $(\mathrm{PH})$, canopy diameter (CD), first bifurcation height (FBH), stem diameter (SD), leaf length (LL), leaf width (LW), fruit weight (FW), fruit length (FL), largest fruit diameter (LFD), smallest fruit diameter (SFD), number of seeds (NS), number of fruits (NF). The qualitative descriptors used were: color of the immature fruit (CIF), color of the intermediate fruit (CIF), color of the mature fruit (CMF), fruit shape (FS), fruit persistence with the pedicel (FPP), pedicel persistence with the stem (PPWS), stem color (SC), stem shape (SS), growth habit (GH), branching density (BD), leaf color (LF), and leaf shape (LS), all based on the Capsicum descriptors proposed by IPGRI (1995). The experimental design was completely randomized. Each experimental unit consisted of one plant per pot. three families of an $\mathrm{F}_{4}$ population were evaluated, each with 45 plants.

The genotypes were represented in a graphic form through the non-metric multidimensional scaling technique based on qualitative, quantitative, and mixed characteristics, with the last one considering the joint analysis of both qualitative and quantitative descriptors.

For the analysis of the quantitative variables, a distance matrix based on the generalized distance of Mahalanobis was obtained through the expression:

$\mathrm{D}_{\mathrm{ii}}^{2}=\delta^{-1} \Psi^{-1}$

In which $\mathrm{D}^{2}{ }_{\mathrm{ii}}=$ distance between genotypes i and i'; $\Psi=$ residual covariance matrix; $\delta$ ' $=\left[\mathrm{d}_{1}, \mathrm{~d}_{2}, \ldots \mathrm{d}_{\mathrm{n}}\right]$, in which $\mathrm{d}_{\mathrm{n}}=$ $Y_{i j}-Y_{i, j}$ and $d_{n}=$ represents the difference between the mean of two genotypes $i$ and i' for each evaluated characteristic; $\mathrm{Y}_{\mathrm{ij}}=$ mean of the $\mathrm{i}$-nth genotype in relation to the $\mathrm{j}$-nth descriptor.

The distance matrix with the qualitative data was constructed using Gower's distance (Gower, 1971), employing the equation:

$\mathrm{S}_{\mathrm{ij}}=\frac{\sum_{\mathrm{k}=1}^{\mathrm{n}} \mathrm{W}_{\mathrm{ijk}} \mathrm{S}_{\mathrm{ijk}}}{\sum_{\mathrm{k}=1}^{\mathrm{n}} \mathrm{W}_{\mathrm{ijk}}}$

In which $S_{i j}$ is the similarity between genotypes $\mathrm{i}$ and $\mathrm{j}, W_{i j k}$ = weight attributed to the $\mathrm{i}_{\mathrm{jk}}$ comparison, attributing the value 1 for the valid comparisons and the value 0 for the invalid comparisons (when the value of the variable is absent in either one or both individuals). $S_{i j k}=1$, the contribution of the $\mathrm{k}$ variable in the similarity between individuals $\mathrm{i}$ and $\mathrm{j}$, with values between 0 and 1 . For a nominal variable, if the value of the $k$ variable is the same for individuals $i$ and $j$, then $=1$, otherwise, it will be equal to 0 . Thus, $d_{i j}=1-S_{i j}$.

The non-metric multidimensional scaling (nMDS) was used for the graphic representation of the distance matrixes in the bidimensional space. The level of adjustment (or lack of adjustment) in the nMDS mapping was calculated through Kruskal's Stress.

$\operatorname{Stress}_{1}=\left[\frac{\sum_{\mathrm{i}=1}^{\mathrm{n}-1} \sum_{\mathrm{j}>1}^{\mathrm{n}}\left(\mathrm{d}_{\mathrm{ij}} \widetilde{\mathrm{d}}_{\mathrm{ij}}\right)^{2}}{\sum_{\mathrm{i}=1}^{\mathrm{n}-1} \sum_{\mathrm{j}>1}^{\mathrm{n}} \widetilde{\mathrm{d}}_{\mathrm{ij}}{ }^{2}}\right]^{\frac{1}{2}}$

In which $\mathrm{d}_{\mathrm{ij}}=$ distance between genotypes $\mathrm{i}$ and $\mathrm{j}$; $\widetilde{\mathrm{d}}_{\mathrm{ij}}=$ mapped distance between genotypes $i$ and $j$. The table of stress values proposed by Sturrock and Rocha (2000) was used to validate the result obtained with the nMDS 
solution, by comparing the value obtained with the stress value generated from the matrixes with the same number of objects and the same number of dimensions. All analyses were performed with the R software, version 4.0.1 (R Core Team, 2020).

\section{RESULTS AND DISCUSSION}

The non-metric multidimensional scaling technique (nMDS) presented distances between the genotypes of three families $(17.18 ; 30.16 ; 56.8)$ of pepper plants in a

Table 1: Stress values (Kruskal,1964) associated to the nonmetric multidimensional scaling analysis for 45 genotypes of the $17.18,30.16$ and 56.8 families regarding qualitative, quantitative, and mixed characteristics of ornamental pepper plants (Capsicum annuum L.)

\begin{tabular}{lccc}
\hline Family & Qualitative & Quantitative & Mixed \\
\hline 17.18 & $22.83 \%$ & $17.31 \%$ & $23.52 \%$ \\
30.16 & $15.62 \%$ & $20.00 \%$ & $20.00 \%$ \\
56.8 & $20.00 \%$ & $10.41 \%$ & $19.59 \%$ \\
\hline
\end{tabular}

graphic form, in which a dispersion can be observed in the qualitative, quantitative, and mixed data, indicating the occurrence of genetic variability in the $\mathrm{F}_{4}$, with more selection cycles being useful to proceed with the improvement program of ornamental pepper plants aiming to obtain new lineages.

The stress varied from $10.41 \%$ to $23.53 \%$ in the analyzed families for the qualitative, quantitative, and mixed characteristics (Table 1). According to the table proposed by Sturrock \& Rocha (2000), with $\mathrm{n}=45$ genotypes, $\mathrm{k}=2$ dimensions, there is a probability $(\mathrm{p}<0.01)$ that the genotypes will be randomly arranged in the bidimensional space.

Furthermore, stress values up to $20.00 \%$ are acceptable in this type of analysis (Kruskal et al., 1964; Meyer et al., 2004). The stress values obtained indicate a good ordination in the qualitative data for families $17.18 ; 30.16$, and 56.8, and in the quantitative and mixed data for families 30.16 and 56.8. Thus, through this analysis, it was possible to identify the more divergent genotypes, which contain a
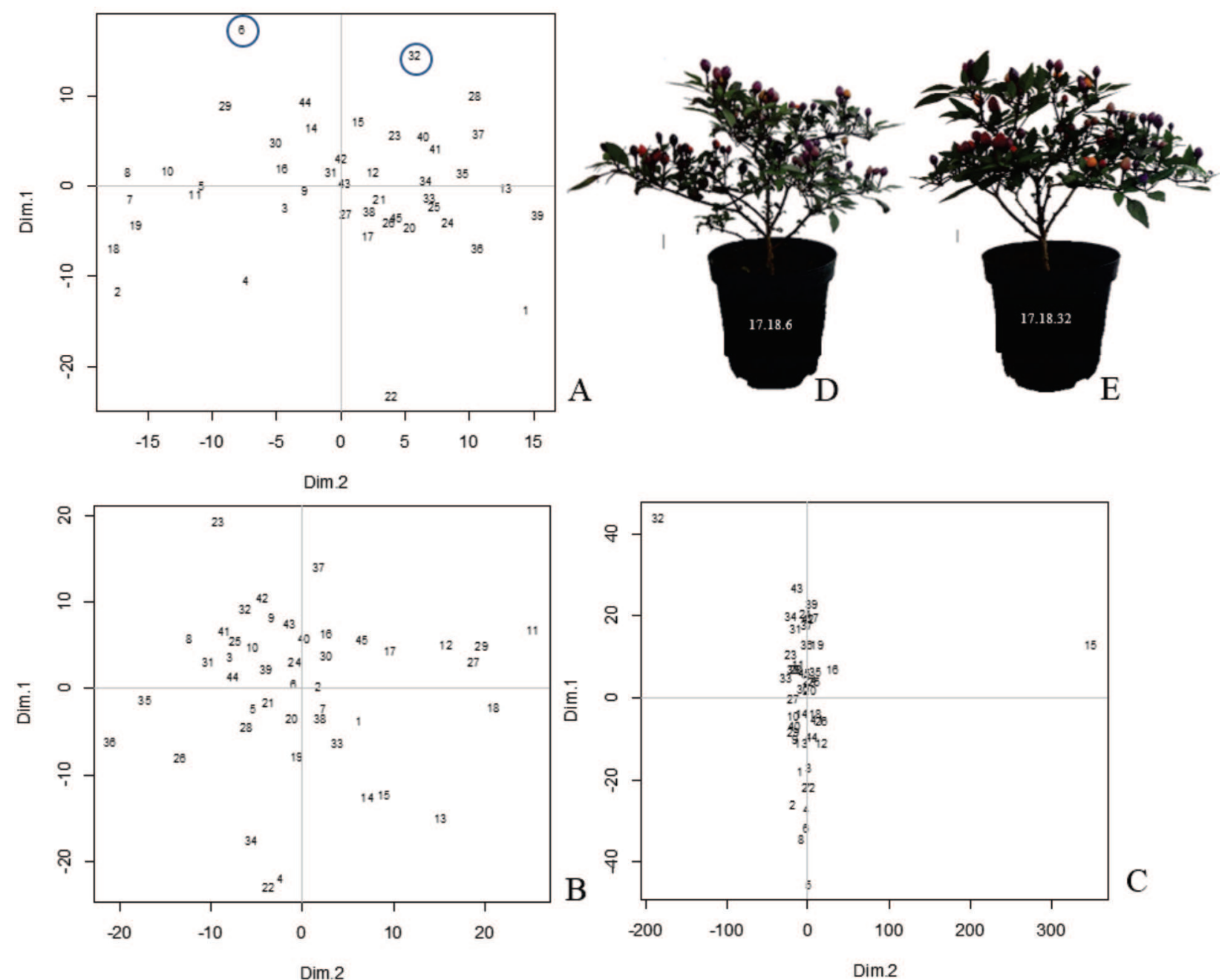

Figure 1: Graphic representation of the bidimensional scaling based on the quantitative data of the 17.18 (A), 30.16 (B), and 56.8 (C) families of 45 genotypes of Capsicum annuum. Genotypes 17.18.6 (D), 56.18 .32 (E). Bar corresponding to $2 \mathrm{~cm}$. Areia-PB. CCAUFPB-2020.

Rev. Ceres, Viçosa, v. 67, n.6, p. 474-481, nov/dec, 2020 
phenotype of in-pot ornamental interest. In this study, the dispersion based on quantitative and mixed data for the 17.18 family was unsatisfactory. This indicates that the representation of the distances in the bidimensional space is not an appropriate choice (Silva, 2016).

According to the quantitative analysis of the 17.18 family, the most distant genotypes in the graphic were the 6, 32, 28, 1, 4, and 2 (Figure 1A). Genotype 6 presented smaller size, fruits, and leaves, Genotype 32 presented a wider canopy diameter and a lower first bifurcation height. Genotype 28 presented a smaller stem diameter and smaller fruits. Genotype 1 presented a large size and larger leaves, contrasting with genotype 2 , which, in spite of presenting a large size, presents small leaves. Genotype 4 presented a wider leaf width (Table 2). Among the most distant individuals, those that presented interesting characteristics for the in-pot ornamental pepper were genotypes 6 and 32 (Figure 2D and 2E), for possessing small fruits and leaves allied to a small size, adapting to the pot and able to be recommended for use in the improvement of the ornamental pepper (Büttow et al., 2010; Costa et al., 2019), being attractive to the customer at the time of purchase (Neitzke et al., 2016).

For the family 30.16 , in the quantitative data analysis, the genotypes that stood more distant were the 23, 37, 11 , $18,13,22,2,36$, and 34 (Figure 1B). Among the more distant genotypes, which presented desirable characteristics for the in-pot ornamental pepper plant, genotypes 22, 36, and 34 (Figure 1B) are highlighted. Genotype 22 presented the greatest number of fruits. Genotype 36 exhibited low size and a lower first bifurcation height, whereas genotype 34 presented smaller leaves and fruits (Table 2). For ornamental purposes, the selection of plants with these characteristics is recommended (Finger et al., 2012; Silva et al., 2015; Bianchi et al., 2016; Bãrcanu et al., 2017) to continue the improvement program with ornamental pepper plants.

It is observed that the family 56.8 presented a lower dispersion of genotypes, indicating a greater homogeneity of the plants within this family when compared to the other families. It is then notorious that this family is closest to homozygosis. In spite of the existence of very close genotypes, only genotypes 32,15 , and 5 were distant for the quantitative characteristics (Figure 1C). Genotype 32 presented smaller leaves and larger fruits; conversely, plant 15 presented a smaller size and a lower first bifurcation height, whereas individual 5 presented a smaller stem diameter (Table 2). Among these more distant individuals, the selection of genotype 5 is recommended for presenting desirable descriptors for the in-pot ornamental pepper plant. Santos et al. (2014) affirm that is important to select pepper genotypes that present plant and fruit sizes adequate to in-pot cultivation, aiming at the decoration of internal spaces.

Table 2: Quantitative descriptors of families 17.18, 30.16, and 56.8 of pepper plants (Capsicum annuum L.)

\begin{tabular}{|c|c|c|c|c|c|c|c|c|c|c|c|c|}
\hline 17.18 & PH & CD & FBH & SD & $\mathbf{L}$ & LW & FW & $\mathbf{F L}$ & LFD & SFD & NS & NF \\
\hline 1 & 32.0 & 26.0 & 16.0 & 0.49 & 3.81 & 1.53 & 0.73 & 1.56 & 0.97 & 0.26 & 30 & 46 \\
\hline 2 & 31.0 & 35.0 & 12.5 & 0.50 & 2.00 & 1.67 & 0.45 & 1.05 & 0.87 & 0.33 & 25 & 46 \\
\hline 4 & 30.0 & 31.0 & 15.0 & 0.47 & 3.00 & 1.90 & 0.40 & 0.92 & 0.84 & 0.36 & 19 & 39 \\
\hline 6 & 23.0 & 28.0 & 15.0 & 0.59 & 2.13 & 0.88 & 0.34 & 0.84 & 0.74 & 0.25 & 15 & 35 \\
\hline 28 & 23.0 & 26.0 & 16.0 & 0.44 & 3.52 & 1.31 & 0.30 & 0.79 & 0.74 & 0.29 & 12 & 51 \\
\hline 32 & 23.0 & 37.0 & 11.0 & 0.64 & 3.25 & 1.24 & 0.69 & 1.10 & 0.95 & 0.34 & 28 & 30 \\
\hline 30.16 & PH & CD & FBH & SD & $\mathbf{L}$ & LW & FW & $\mathbf{F L}$ & LFD & SFD & NS & NF \\
\hline 2 & 24.0 & 33.0 & 14.0 & 0.56 & 2.06 & 1.02 & 0.35 & 1.17 & 0.70 & 0.33 & 26 & 60 \\
\hline 11 & 27.0 & 36.0 & 14.0 & 0.64 & 2.17 & 1.13 & 0.73 & 1.65 & 0.82 & 0.39 & 48 & 76 \\
\hline 13 & 32.0 & 35.0 & 16.0 & 0.62 & 2.07 & 0.93 & 0.41 & 1.43 & 0.75 & 0.30 & 22 & 91 \\
\hline 18 & 28.0 & 29.0 & 14.0 & 0.56 & 2.49 & 1.35 & 0.58 & 1.48 & 0.84 & 0.37 & 41 & 83 \\
\hline 22 & 21.0 & 28.0 & 12.0 & 0.52 & 1.90 & 0.84 & 0.16 & 0.76 & 0.51 & 0.31 & 10 & 99 \\
\hline 23 & 20.0 & 19.0 & 13.0 & 0.52 & 1.95 & 0.81 & 0.20 & 0.78 & 0.60 & 0.35 & 30 & 49 \\
\hline 34 & 24.0 & 36.0 & 12.0 & 0.44 & 1.64 & 0.56 & 0.17 & 0.77 & 0.53 & 0.25 & 12 & 86 \\
\hline 36 & 20.0 & 30.0 & 9.0 & 0.27 & 1.32 & 0.61 & 0.38 & 1.13 & 0.76 & 0.33 & 28 & 48 \\
\hline 37 & 22.0 & 28.0 & 11.0 & 0.76 & 2.39 & 1.18 & 0.49 & 1.40 & 0.79 & 0.33 & 25 & 45 \\
\hline 56.8 & PH & CD & FBH & SD & $\mathbf{L}$ & LW & FW & $\mathbf{F L}$ & LFD & SFD & NS & NF \\
\hline 5 & 25.0 & 33.0 & 13.0 & 0.42 & 3.14 & 1.25 & 0.61 & 1.22 & 0.64 & 0.32 & 47 & 61 \\
\hline 15 & 31.0 & 31.0 & 14.0 & 0.48 & 3.10 & 1.54 & 0.90 & 1.72 & 1.03 & 0.30 & 30 & 35 \\
\hline 32 & 22.0 & 25.0 & 13.0 & 0.65 & 2.76 & 1.26 & 1.31 & 2.25 & 1.18 & 0.29 & 27 & 38 \\
\hline
\end{tabular}

$(\mathrm{PH})$ plant height $(\mathrm{cm}),(\mathrm{CD})$ canopy diameter $(\mathrm{cm}),(\mathrm{FBH})$ first bifurcation height $(\mathrm{cm}),(\mathrm{SD})$ stem diameter $(\mathrm{cm}),(\mathrm{LL})$ leaf length $(\mathrm{cm})$, (LW) leaf width $(\mathrm{cm}),(\mathrm{FW})$ fruit weight $(\mathrm{g})$, (FL) fruit length $(\mathrm{cm})$, (LFD) largest fruit diameter $(\mathrm{cm})$, (SFD) smallest fruit diameter (cm), (NS) number of seeds, (NF) number of fruits 
Other works have demonstrated the distance of the genotypes in a graphic form through the non-metric multidimensional technique using quantitative data, such as that by Silva et al. (2014), who used the non-metric multidimensional scaling analysis based on quantitative data for the identification of garlic genotypes based on different phenotypical characteristics. Barroso et al. (2019) used the analysis in the selection of more divergent broad bean genotypes, having quantitative data as a base (Pessoa et al., 2019), and also selecting genotypes in a segregating population of pepper plants based on quantitative data.
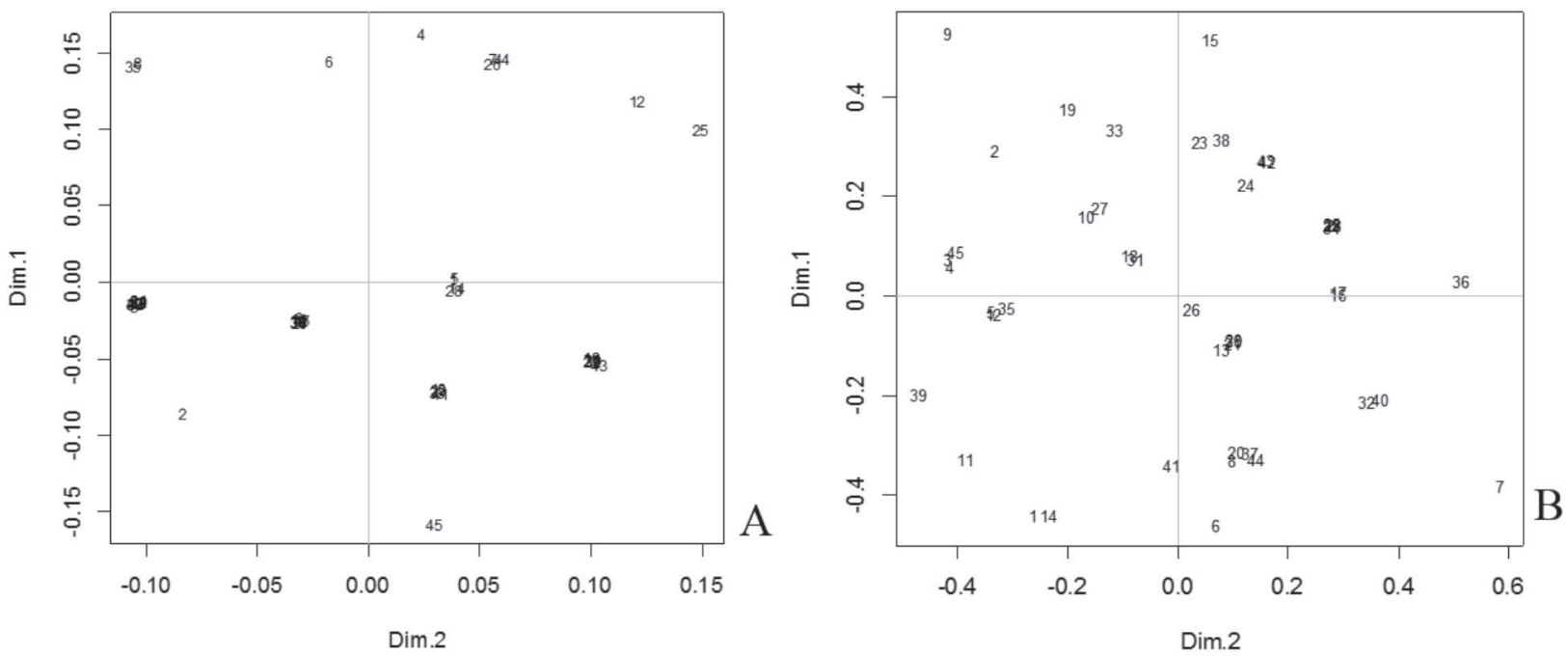

Figure 2: Graphic representation of the multidimensional scaling of the families based on qualitative data. Families 30.16 (A) and 56.8 (B), each with 45 Capsicum annuum genotypes. Areia-PB. CCA-UFPB-2020.

Table 3: Qualitative descriptors of families 30.16 and 56.8 of ornamental peppers (Capsicum annuum L.)

\begin{tabular}{lcccccc}
\hline $\mathbf{3 0 . 1 6}$ & CIM & CIF & CMF & FS & FPP & PPWS \\
\hline 2 & Light green & Yellow /orange & Red & Triangular & Persistent & Persistent \\
4 & Light green & Yellow & Orange & Triangular & Intermediate & Intermediate \\
12 & Light green & Yellow & Orange & Triangular & Intermediate & Intermediate \\
25 & Light green & Yellow & Orange & Triangular & Intermediate & Intermediate \\
45 & Light green & Yellow/ orange & Red & Triangular & Persistent & Intermediate \\
\hline $\mathbf{3 0 . 1 6}$ & S C & S S & GH & BD & LF & LS \\
\hline 2 & Green & Angular & Intermediate & Intermediate & Dark green & Oval \\
4 & Green & Angular & Intermediate & Intermediate & Dark green & Lanceolate \\
12 & Green & Angular & Intermediate & Intermediate & Dark green & Lanceolate \\
25 & Green & Angular & Intermediate & Intermediate & Dark green & Oval \\
45 & Green & Angular & Intermediate & Intermediate & Light green & Oval \\
\hline $\mathbf{5 6 . 8}$ & CIM & CIF & CMF & FS & FPP & PPWS \\
\hline 6 & Purple & Brown /yellow & Orange & Triangular & Intermediate & Light \\
7 & Green/Purple & Yellow & Orange & Triangular & Intermediate & Light \\
9 & Purple & Brown /yellow & Orange & Triangular & Persistent & Light \\
15 & Purple/Brown & Brown /yellow & Orange & Triangular & Persistent & Light \\
36 & Purple & Yellow & Orange & Triangular & Intermediate & Light \\
\hline $\mathbf{5 6 . 8}$ & S C & S S & GH & BD & LF & LS \\
\hline 6 & Green/ strips & Cylindrical & Intermediate & Intermediate & Green & Oval \\
7 & Green/ strips & Cylindrical & Intermediate & Intermediate & Green & Lanceolate \\
9 & Green/ strips & Cylindrical & Erect & Scarce & Light green & Lanceolate \\
15 & Green/ strips & Angular & Intermediate & Intermediate & Light green & Lanceolate \\
36 & Green/ strips & Angular & Intermediate & Intermediate & Dark green & Lanceolate \\
\hline
\end{tabular}

color of the immature fruit (CIF), color of the intermediate fruit (CIF), color of the mature fruit (CMF), fruit shape (FS), fruit persistence with the pedicel (FPP), pedicel persistence with the stem (PPWS), stem color (SC), stem shape (SS), growth habit (GH), branching density (BD), leaf color (LF), and leaf shape (LS).

Rev. Ceres, Viçosa, v. 67, n.6, p. 474-481, nov/dec, 2020 
Observing the qualitative data of family 30.16 , the more distant genotypes were the $6,4,12,25,45$ and 2 (Figure 2A). These individuals presented differences for the qualitative variables (fruit color in the intermediate and mature stage, fruit persistence with the pedicel, and pedicel persistence with the stem, leaf color, and leaf shape). The genotype with more desirable characteristics for ornamental purposes was genotype 4 , presenting fruits with yellow and orange coloration, more persistent fruits with the pedicel, and dark green color of the leaves, with a lanceolate shape (Table 3 ). The color of fruits and leaves are aesthetical aspects that turn the ornamental pepper plants into good alternatives for the market of in-pot ornamental plants (Stommel \& Griesbach, 2008).

Through the multidimensional scaling for the qualitative data of family 56.8 , the genotypes that were more disperse were the 9, 15, 36, 7, and 6 (Figure 2B). These plants were distanced for presenting different coloration stages of fruits and leaves, growth habit and leaf shape. Genotype 9 presented an erect growth habit and light green leaves, whereas genotype 15 presented fruits with purple and brown coloration, and genotype 36 presented fruits with yellow coloration and dark green leaves. Genotype 7 presented green and purple coloration, whereas genotype 6 presented leaves with an oval shape (Table 3). The most interesting genotypes for ornamental purposes were the 15, 36, and 7 (Figure 3E and 3F).

In the joint or mixed data analysis for the family 30.16 , the most divergent genotypes were the $4,12,11,22$, and 34 (Figure 3A), among which only the 22 and 4 presented desirable characteristics for ornamental purposes (Figure $3 \mathrm{C}$ and 3D). It is verified that these genotypes, when the quantitative and qualitative data were analyzed separately, also remained distant and presented important characteristics for in-pot ornamental pepper plants. These quantitative and qualitative characteristics found in these genotypes are important regarding the aesthetical aspect of the plants. In this perspective, there is a demand in Brazil for new pepper cultivars that present features of ornamental interest, destined for in-pot cultivation (Nascimento et al., 2014; Neitzke et al., 2016).

Based on the mixed data of family 56.8, the most distant genotypes were the $15,36,32,7$, and 9 , and can be
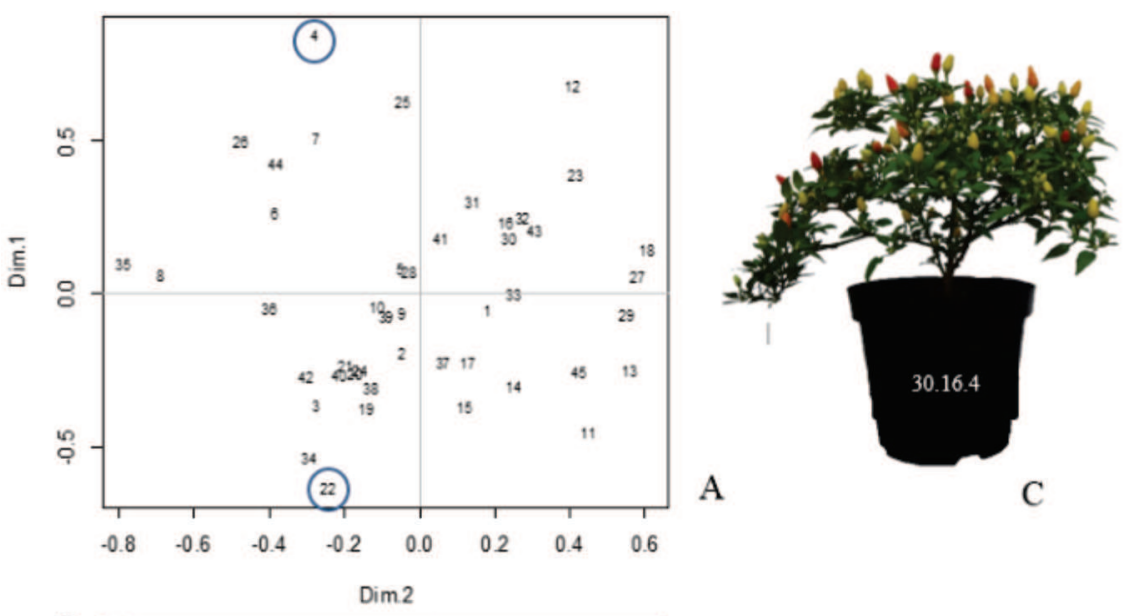

A

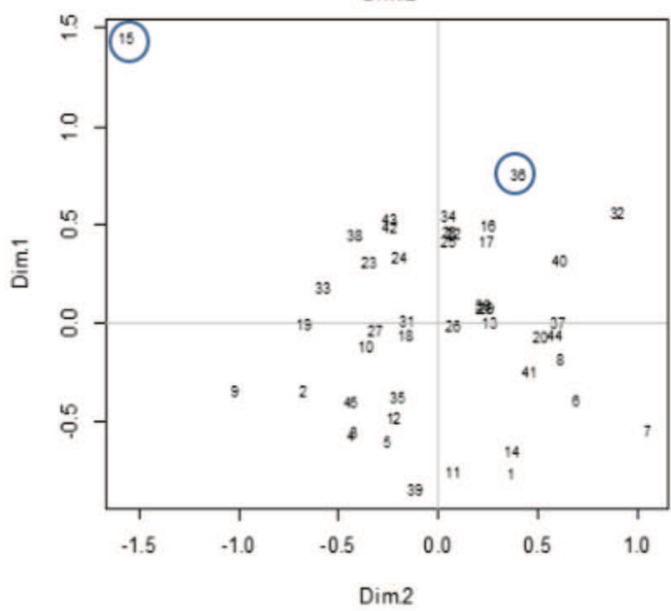

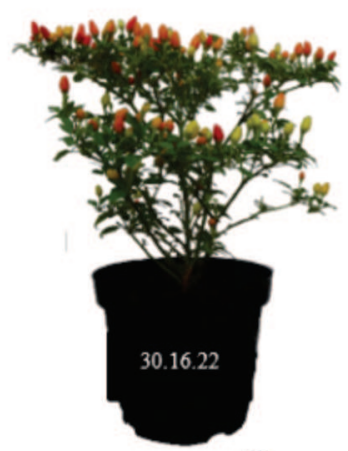

D

Figure 3: Graphic representation of the multidimensional scaling of the families based on mixed data (qualitative and quantitative). Families 30.16 (A) and 56.8 (B), each with 45 Capsicum annuum genotypes. Genotypes 30.16.4 (C), 30.16.22 (D), 56.8 .15 (E), 56.8.36 (F). Bar corresponding to $2 \mathrm{~cm}$. Areia-PB. CCA-UFPB-2020. 
considered the most divergent (Figure 3B). All these genotypes were also distant when separately observing the qualitative and quantitative analyses. Therefore, the selection of genotypes 15 and 36 is recommended, which also stood distant in this analysis. These genotypes, as previously reported, presented desirable characteristics for in-pot ornamental purposes. Furthermore, the fruit coloration of the pepper plants found in the selected genotypes is of extreme importance in the selection of individuals due to the color variation in the maturation stages, making them more attractive and arousing the interest of the consumers for decorative purposes (Silva et al., 2015).

The non-metric multidimensional scaling analysis showed to be efficient to study the distances of the pepper genotypes. Some authors observed the importance of using the mixed variable analysis, employing Gower's distance to analyze the genetic diversity in Capsicum (Sudré et al., 2010; Moura et al., 2010; Rocha et al., 2010; Cardoso et al., 2018). It is worth noting that when using the joint analysis since there is an acceptable stress level, it is possible to better discriminate desirable genotypes for selection. Therefore, this technique is a strategy that must be considered for the study of diversity in segregating populations of Capsicum, especially when combined with the joint analysis of qualitative and quantitative characters. Therefore, a joint analysis of variables can provide a more complete indicator of the diversity in improvement programs (Gomes et al., 2019).

\section{CONCLUSION}

There is genetic diversity within the analyzed families based on the multidimensional scaling using the distances of the genotypes, allowing the practice o selection.

In the quantitative and mixed variable data, family 30.16 is the most divergent; in the qualitative data, it is family 56.8 .

The selection in family 17.18 of genotypes 6 and 32 is recommended, as well as in family 30.16 of genotypes 22 and 4 , and family 56.8 of genotypes 15 and 36, since they present important characteristics for ornamental purposes, allowing the continuity of the improvement program for in-pot ornamental pepper plants.

The selection of genotypes is more efficient when using mixed data since it provides a more complete genetic diversity in an improvement program.

\section{ACKNOWLEDGEMENTS AND CONFLICT OF INTERESTS}

The authors are thankful to CAPES and CNPq by grant of their research fellowship. Authors have declared that no competing interests exist.

\section{REFERENCES}

Bãrcanu E, Vînãtoru C, Zamfir B, Bratu C \& Drãghici E (2017) Characterization of new ornamental chilli genotypes created at VRDS Buzãu. Scientific Papers - Series B, Horticulture, 61:313316.

Barroso PA, Medeiros AM, Santos NP, Silva DCQ, Silva SC \& Gomes RLF (2019) Phenotypic Dispersion of Landrace Lima Bean Varieties Using Multidimensional Scaling. Journal of Agricultural Science, 11:178-185.

Bianchi PA, Dutra IP, Moulin MM, Santos JO \& Santos Júnior AC (2016) Morphological characterization and analysis of genetic variability among pepper accessions. Ciência Rural, 46:11511157.

Borg I \& Groenen PJF (2005) Modern multidimensional scaling: Theory and applications. $2^{\text {nd }}$ ed. New York, Springer. 614p.

Bosland PW, Votava EJ \& Votava EM (2012) Peppers: vegetable and spice Capsicuns. Wallinford, Cabi. 230p.

Büttow MV, Barbieri RL, Neitzke RS, Heiden G \& Carvalho FIF (2010) Diversidade genética entre acessos de pimentas e pimentões da Embrapa Clima Temperado. Ciência Rural, 40:12641269.

Cardoso R, Ruas CF, Giacomin RM, Ruas PM, Ruas EA, Barbieri RL, Rodrigues R \& Gonçalves LSA (2018) Genetic variability in Brazilian Capsicum baccatum germplasm collection assessed bymorphological fruit traits and AFLP markers. Plos One, 13:64-68.

Costa GN, Silva BMP, Lopes ACA, Carvalho LCB \& Gomes RLF (2019) Seleção de acessões de pimenta com potencial ornamental. Revista Caatinga, 32:566-574.

Filgueira FAR (2000) Novo manual de Olericultura: tecnologia moderna na produção e comercialização de hortaliças. $2^{\text {nd }}$ ed. Viçosa, Editora UFV. 402p.

Finger FL, Rêgo ER, Segatto FB, Nascimento NFF \& Rêgo MM (2012) Produção e potencial de mercado para pimenta ornamental. Informe Agropecuário, 33:14-20.

Finger FL, Silva TPD, Segatto FB \& Barbosa JG (2015) Inhibition of ethylene response by 1-methylcyclopropene in potted ornamental pepper. Ciência Rural, 45:964-969.

Fortunato FLG, Rêgo ER, Carvalho MG, Santos CAP \& Rêgo MM (2019) Genetic diversity in ornamental pepper plants. Comunicata Scientiae, 10:364-375.

Gomes GP, Baba VY, Santos OP, Sudré CP, Bento CS, Rodrigues R \& Gonçalves LSA (2019) Combinations of distance measures and clustering algorithms in pepper germplasm characterization. Horticultura Brasileira, 37:172-179.

Gower JC (1971) A general coefficient of similarity and some of its properties. Biometrics, 27:857-874.

IPGRI (1995) International plant genetic resources institute. Descriptors for Capsicum. Rome, IBPGR. 49p.

Kruskal JB (1964) Multidimensional scaling by optimizing goodness of fitto a nonmetric hypothesis. Psychometrika, 29:1-27.

Leal JB, dos Santos LM, dos Santos CAP, Pires, JL, Ahnert D \& Carrêa RX (2008) Diversidade genética entre acessos de cacau de fazendas e de banco de germoplasma na Bahia. Pesquisa Agropecuária Brasileira, 7:851-858.

Lima JAM, Rêgo ER, Porcino MM, Silva GHN, Carvalho MG, Santos Pessoa MA \& Rêgo MM (2019) Seleção em população de base de pimentas ornamentais (Capsicum annuum L.). Jornal de Agricultura Experimental Internacional, 3:1-7.

Manly BFJ (2004) Multivariate Statistical Methods: A Primer. $3^{\text {rd }}$ ed. London, Chapman \& Hall. 226p. 
Mesquita JUCP, Rêgo ER, da Silva AR, Silva Neto JJE, Cavalcante LC \& Rêgo MM (2016) Multivariate analysis of the genetic divergence among populations of ornamental pepper (Capsicum аппиит L.). African Journal of Agricultural Research, 11:41894194.

Meyer ADS, Garcia AAF, Souza APD \& Souza Jr CLD (2004) Comparison of similarity coefficients used for cluster analysis with dominant markers in maize (Zea mays L.). Genetics and Molecular Biology, 27:83-91.

Moura MCCL, Gonçalves LSA, Sudré CP, Rodrigues R, Amaral Júnior AT \& Pereira TNS (2010) Algoritmo de Gower na estimativa da divergência genética em germoplasma de pimenta. Horticultura Brasileira, 28:155-161.

Nascimento NFF, Rego ER, Nascimento MF, Bruckner CH, Finger FL \& Rego MM (2014) Combining ability for yield and fruit quality in the pepper Capsicum апnиит. Genetics and Molecular Research, 13:3237-3249.

Nascimento NFF, Rêgo ER, Nascimento MF, Bruckner CH, Finger FL \& Rêgo MM (2019) Evaluation of production and quality traits in interspecific hybrids of ornamental pepper. Horticultura Brasileira, 37:315-323.

Neitzke RS, Fischer SZ, Vasconcelos CS, Barbieri RL \& Treptow RO (2016) Pimentas ornamentais: aceitação e preferências do público consumidor. Horticultura Brasileira, 34:102-109.

Padilha HKM, Sosinski Junior EE \& Barbieri RL (2016) Diversidade morfológica e entropia de pimentão (Capsicum baccatum e Capsicum chinense, solanaceae). International Journal of Current Research, 8:42758-42766.

Pessoa AMDS, Rêgo ERD, Silva APGD, Mesquita JCPD, Silva ARD \& Rêgo MM (2019) Genetic diversity in F3 population of ornamental peppers (Capsicum anпиит L.). Revista Ceres, 66:442-450

R development core team (2020) R: A language and environment for statistical computing. Vienna, R Foundation for Statistical Computing. Accessed on: January $2^{\text {nd }}, 2020$.

Rêgo ER \& Rêgo MM (2018) Ornamental Pepper. In: Van Huylenbroeck J (Ed.) Ornamental Crops. Cham, Springer International Publishing. p.529-565.

Rêgo ER, Rêgo MM \& Finger FL (2015a) Methodological basis and advances for ornamental pepper breeding program in Brazil. Crossing Borders, 1087:309-314.

Rêgo MM, Sapucay MJLC, Rêgo ER \& Araújo ER (2015b) Analysis of divergence and correlation of quantitative traits in ornamental pepper (Capsicum spp.). Acta Horticulturae, 1087:389394

Rocha MC, Gonçalves LSA, Rodrigues R, Silva PRAD, Carmo MGFD \& Abboud AC DS (2010) Uso do algoritmo de Gower na determinação da divergência genética entre acessos de tomateiro do grupo cereja. Acta Scientiarum, Agronomy, 32:423-431.
Santos RMC, do Rêgo ER, Borém A, Nascimento MF, Nascimento NFF, Finger FL \& Rêgo MM (2014) Epistasis and inheritance of plant habit and fruit quality traits in ornamental pepper (Capsicum annuum L.). Genetics and Molecular Research, 13:8876-8887.

Silva AR (2016) Métodos de análise multivariada em R. Piracicaba, Fealq. 167p.

Silva AR, Cecon PR, Dias CTDS, Puiatti M, Finger FL \& Carneiro APS (2014) Morphological phenotypic dispersion of garlic cultivars by cluster analysis and multidimensional scaling. Scientia Agricola, 71:38-43.

Silva CQ, Jasmim JM, Santos JO, Bento CS, Sudré CP \& Rodrigues R (2015) Phenotyping and selecting parents for ornamental purposes in chili pepper accessions. Horticultura Brasileira, 33:66-73.

Silva CQ, Rodrigues R, Bento CS \& Pimenta S (2017) Heterosis and combining ability for ornamental chili pepper. Horticultura Brasileira, 35:349-357.

Silva Neto JJS, Rêgo ER, Nascimento MF, Filho VALS, Neto JXA \& Rêgo MM (2014) Variabilidade em população base de pimenteiras ornamentais (Capsicum annuum L.). Revista Ceres, 61:84-89.

Silvar C \& García-González CA (2017) Screening old peppers (Capsicum spp.) for disease resistance and pungency-related traits. Scientia Horticulturae, 218:249-257.

Stommel JR \& Bosland PW (2006) Ornamental pepper, Capsicum аппиит. In: Anderson NO (Ed.) Flower Breeding and Genetics: Issues, Challenges and opportunities for the $21^{\text {st }}$ Century. Dordrecht, The Netherlands: Springer, p.561-599.

Stommel JR \& Griesbach RJ (2008) Inheritance of Fruit, Foliar, and Plant Habit Attributes in Capsicum. Journal of the American Society for Horticultural Science, 133:396-407.

Sturrock K \& Rocha J (2000) A multidimensional scaling stress evaluation table. Field methods, 12:49-60.

Sudré CP, Gonçalves LSA, Rodrigues R, Amaral Júnior AD, RivaSouza EM \& Bento CDS (2010) Genetic variability in domesticated Capsicum spp. as assessed by morphological and agronomic data in mixed statistical analysis. Genetics and molecular research, 9:283-294.

Vasconcelos CSD, Barbieri RL, Neitzke RS, Priori D, Fischer SZ \& Mistura CC (2012) Determinação da dissimilaridade genética entre acessos de Capsicum chinense com base em características de flores. Revista Ceres, 59:493-498. 